\title{
351. Verlaufsuntersuchung zur psychosozialen Nachsorge bei chirurgisch behandelten Krebspatienten
}

\author{
A. Sellschopp, H. Häberle, M. Kreh, U. Michel, H. Schmidt und R. Schwarz \\ Nachsorgeeinrichtung und Ausbildungsseminar an der Chirurgischen Universitätsklinik Heidelberg, \\ Im Neuenheimer Feld 155, D-6900 Heidelberg
}

\section{Follow-up Study on Psychosocial Aftercare of Surgically Treated Cancer Patients}

Summary. The efficacy of the psychosocial aftercare of cancer patients is tested in a follow-up study of patients of the University Surgical Clinic. The study was devised to achieve conclusions for further research. The representation of the study is preceded by a description of the activities of the aftercare institution.

Key words: Psychosocial - Aftercare - Cancer patients.

Zusammenfassung. Die Wirksamkeit psychosozialer Nachsorge von Krebspatienten wird in einer Verlaufsuntersuchung an Patienten der Chirurgischen Universitätsklinik überprüft. Die Untersuchung wurde im Hinblick auf Schlußfolgerungen für weitere Forschung angelegt. Der Darstellung dieser Untersuchung ist eine Beschreibung der Tätigkeiten der Nachsorgeeinrichtung vorangestellt.

Schliisselwörter: Psychosozial - Nachsorge - Krebspatienten.

\section{Thoraxdeformitäten - Klassifizierung, Operationsindikation, Operationstechnik, Spätergebnisse}

\author{
G. H. Willital, H. Hümmer und H. Meier \\ Chirurgische Universitätsklinik Erlangen (Prof. Dr. F. P. Gall), Kinderchirurgie (Prof. Dr. G. H. Willital), \\ Maximiliansplatz, D-8520 Erlangen
}

\section{Thoracic Deformity; Classification, Indication, Operative Technique, Late Results}

Summary. There are different kinds of chest deformity: funnel chest, pigeon chest, combined funnel and pigeon chest. There are altogether 11 different types. The operative procedure and the prognosis are different depending on the type. Necessary investigations are: to determine the external sagittal thoracic diameter, the internal sagittal diameter, the funnel chest index and the transverse thoracic profile. Indication for operative treatment are chest deformities with a depression of over $25 \%$ of the normal thorax if there is a funnel chest index below 110. There are secondary changes of other organs: scoliosis and kyphosis, pathological ECG, increased pressure in the right atrium and right ventrical similar to constrictive pericarditis. CT investigations demonstrated an inhibition of the venous back-flow to the heart. Operative treatment is performed with trans-sternal metal struts for anatomical reconstruction of the thorax. A total of 1,442 funnel chests have been operated on; the recurrency rate is $1.5 \%$.

Key words: Funnel chest - Pigeon chest - Operative treatment.

Zusammenfassung. Thoraxdeformitäten umfassen: Trichterbrust, Kielbrust, kombinierte Kiel-Trichterbrüste und Sonderformen. Man unterscheidet insgesamt 11 Typen, danach richtet sich das operative Vorgehen, die Prognose ist entsprechend unterschiedlich. Beurteilung der Thoraxdeformität erfolgt durch Thoraxvermessungen : 1. äußerer sagittaler Durchmesser, 2. innerer sagittaler Durchmesser, 3. Trichterbrustindex, 4. Thoraxquerschnitt mit einem flexiblen Lineal. Indikation zur operativen Korrektur ist gegeben bei Einsenkungen über $25 \%$ der normalen Thoraxtiefe bzw. bei einem Trichterbrustindex unter 110 . Sekundärveränderungen sind: in $60 \%$ Skoliosen und Kyphosen. EKG: Arhythmie, Rechts-Linksschenkelblock, Rechtsherzbelastung, pathologische Herzkatheteruntersuchungen. EKG-Bild ähnlich wie bei einer Pericarditis constrictiva, CT-Untersuchungen: venöse Rückflußstörungen zum Herzen, Kompression im Lungenhilus, Lungenemphysem in überdehnten Lungenabschnitten. Die operative Korrektur erfolgt unter Zuhilfenahme von einem oder mehreren Metallbügeln transsternal, die eine anatomisch gerechte Rekonstruktion des Thorax ermöglichen. 1442 Trichterbrüste wurden operiert, die Rezidivquote lag bei $1,5 \%$.

Schliisselwörter: Trichterbrust - Kielbrust - Operatives Vorgehen. 